external laryngeal was not ascertained at the time of the operation; the main trunk of the vagus was certainly behind the neck of the pouch. It is not possible, therefore, to say whether the external laryngeal was in front of the neck, as it onght to have been if the pouch were connected with the third or some lower cleft; it is, however, almost certain that it did occupy this position.

The relation of the carotid arteries to the clefts is not yet definitely settled, and the issue is confused by the fact that the embryo of the chick has been so much employed in the study of embryology and that the development of the carotids does not appear to be the same in birds as in mammalla. Another source of confusion arises from the fact that the vessels are displaced downwards (towards the thorax) in the course of development.

According to many good authorities, the external carotid is developed from the ventral aortic vessel and thus passes in front of the visceral arches, the internal carotid from the third arch and that part of the dorsal aortic vessel which is above (anterior to) it. If, then, this pouch were developed from the third cleft its neck ought to have passed behind the two carotids. But such was not the case. Both carotids were behind the neck and only one explanation suggests itself-that the pouch was quite small at the time when the vessels were being displaced downwards (towards the chest) and that in its subsequent growth it pushed up in front of the external carotid.

If we turn to the descriptions of other observers it is found that it is not infrequent for the neck of the pouch to pass between the external and internal carotids and that the relation of some of them to the second cleft appears to have been clearly made ont. Thus König, Watson, Heuter, Rehn. Tricomi, and Gassenbauer all noted that the canal passed beneath the lower border of the digastric, and Watson and Heuter traced it between the external and internal carotid arteries to the pharynx, the seventh nerve lylng above it and the ninth nerve and the stylo-hyoid ligament below it. This seems to have been the course of the canal in the very few cases that have been dissected post mortem. Some others have been traced into the same position by operation, but though a few others, like the present case, have been traced up to the thyro hyoid membrane in operation the exact position of the internal opening has not been ascertained. In Watson's case a branch of the ninth nerve innervated the walls of the pouch and in the case recorded by Berger probing of the fistula caused cough and stopping of the pulse and other symptoms of distress thought to be due to irritation of the superior laryngeal nerve. In Cavazzani's case vomiting followed the use of the probe. In most cases the walls were found to consist of fibrous tissue and striped muscular fibres have been noted by some observers. The lining epithelium was either of the stratified fldttened variety or columnar and ciliated as in the present case. König noted two canals side by side, one lined with flattened and the other with columnar ciliated epithelinm, and otber observers have described pouches lined with flattened epithelium below and columnar and ciliated at the upper part-that is to say, the part of the pouch nearest to the pharynx.

The facts pointing to the congenital origin of pharyngeal ponches and fistalæ and to their probable connexion with the visceral clefts may be summarised as follows. 1. They are frequently hereditary. 2. They are often bilateral. 3. Though they of ten do not appear till early adult life they may be present as fistulæ at birth or very early in life, and it is probable that they are of ten overlooked, as the symptoms they give rise to are slight and may take some time to develop. 4. The peculiar course of the canal. 5. The presence of a lining of ciliated epithelium, although they are derived from a portion of the pharynx normally covered with squamous epithelium. 6 . The fact that the neck of the canal or pouch often passes between the carotids in the position of the second visceral cleft. 7. The fact that striated muscle bas been found in the wall of such pouches and fistulæ, and that in one case a band of striated muscle ran from the end of the ponch down the course usually pursued by complete fistulæ. 8. The fact that in several cases glands having a similar structure to the normal mucous salivary glands have been found opening into the lumen of pouches and fistulæ. This may account for the discharge noted in cases like the present. One of us has met with an instance, many years ago, of a cyst, then supposed to be developed in connexion with the bursa beneath the hyoid, which was, however, lateral in position, and which it was found impossible to dissect out. The patient, who was under the care of Lord Lister, was a distinguished advocate, and he was much troubled after the operation by a mucous discharge from the fistula which occurred when he was speaking in court. The fistula, after many years, closed. 9. The fact that around the lumen a considerable quantity of lymphoid tissue was noted by König in three cases and also by others, while cartilage has occasionally been met with in the walls of such fistulæ.

As this pouch was obviously of the pharyngeal variety no reference is here made to the so-called pressure pouches of the oesophagus, but it is at least possible that some of these should be placed in the same category.

Bibliography. - The following references include nearly all the recorded cases. The writings giving most information on the subjeot are marked with an asterisk. ${ }^{*}$ Kostanecki and $v$ on Mielicki : Archi fiur Pathologische Anatomie, 1890, exxi., pp. 55 and 247, containing a fur Pathologische Anatomie, 1890 , exxi., pp. 55 and 247 , containing a
summary of all cases up to the year 1890 . Sachs : Jubiläum von Theo. Kocher, Wiesbaden, 1891, p. 63. Hektoen: Chicago Medical Theo. Kocher, Wlesbaden, 1891, p. 63. Hektoen : Chicago Medical
Record, 1891, ii., p 128. Tietze : Zeitschrift für Chirurgie, Leipsic, Record, 1891, ii., p 128. Tietze : Zeitschrift für Chirurgie, Leipsia, p. 541. Cavazzani : Riforma Medica, Napoli, 1891, iv., p. 31. * Paci: S. 541. Cavazzanim : Riforma Medile, 189l, xlv., p. 425. * Lejars: Progrès Mérical, Paris, Sperimentale, 1891, xlv., p. 425. * Lejars: Progrès Mérical, Paris, Société de Chirurgie; Paris, 1892, xviii. pp. 75-80. $*$ GussenSociété de Chirurgie; Paris, 1892, xviii., pp. 75-80. * Gussen$\begin{array}{llll}\text { bauer : Beiträge zur Chirurgie, von Billroth, } 1892, & \text { pp. } & 250- \\ 286 & \text { Arndt: } & \text { Berliner Klinische Wochensehrift, 1892 p. } 532 .\end{array}$ Shattock : Transactions of the Pathological Society of London, 1892, xliv., p. 62. Schlange : Archiv für Klinische Chirurgie, Berlin, 1893, xlvi., pp 390-392. *Karewski : Archiv für Pathologische Anatomie, Berlin, 1893, cxxxiii., pp. 237-249. Buscarlet: Revue Médicale de la Suisse, 1893, xiii., p. 1. Sulicka : These doct . Paris, 1893-94, No. 492. Parker : Bristol Medico-Chirurgical Journal, 1893, xi, p 1. Hamann:
Cleveland Medical Gazette, 1893-94, ix, pp. 110-112. *Giordano : Riforma Merica, Napoli, 1895 , xi, pp. 530-544. Kopfstein : Wiener Klinische Rundschau, 1895, ix., p. 41. Lichtwitz: Gazette Hebdomadaire de la Société de Médecine, Bordeaux, 1895, xvi p. 471. König : Archiv für Klinische Chirurgie, Berlin, 1896, li, pp 578-618. Kontnik: Gazette Hebdomadaire, Paris, 1896, xliii., pp. 1216-1218. Binnie: Kansas City Medical Index, 1897, xviii., pp. 49-53. Von Hacker: Centralblatt fur Chirurgie, Leipsic, 1897. xxiv., pp. 10731076. De Stella: Annales de la société de Médrcine de Gand, 1898, lxxviii., pp. 174-181. "Sultan: Deutsche Zeitschrift fiir Chirurgie, Leipsic, 1898, xlviii, pp. 113-155. Vaughan: Brit. Med Jour., 1899, i., p. 148. *Nieny :-Beiträge zur Klinischen Chirurgie, Tübingen, 1899, xxiil., pp. 89-108. Pouches similar in many ways to the one forming Kirchner, Schmidt, Kostanecki, and Kopfstein. The references of the first six will be found in Kostanecki's paper mentioned above.

\section{FLIES AND THE SCIENCE OF SCAVENGING.}

BY G. V. POORE, M.D., F.R.C.P. LOND., PHYSICIAN TO UNIVERSITY COLLEGK HOSPITAL; PROFESBOR OF MEDICINE, UNIVERSITY OOLLEGE, LONDON.

IN the recent debate ${ }^{1}$ at the Clinical Society of London on Dr. H. H. Tooth's paper ${ }^{2}$ on Enteric Fever in South Africa it was established: (1) that the number of flies in our camps was prodigious; and (2) that these flies were largely a result of the military occupation. There seems also to have been a very general consensus of opinion (3) that flies may convey infection. It becomes therefore of great importance to consider the genesis of flies; and I trust that one who has no claims to be considered a dipterologist may be pardoned for recalling a few common facts.

Flies multiply at a prodigious rate. Given a temperature sufficiently high to batch the eggs, their numbers are only limited by the amount of food available for them. Linnæus is credited with the saying that three meatflies, by reason of their rapid multiplication, would consume a dead horse quicker than would a lion, and the fact that certain diptera baving some outward resemblance to the boneybee lay their eggs in the dead carcasses of animals probably led Samson and Virgil to make erroneous statements with regard to the genesis of honey and the manufacture of bees. The breeding of "gentles" for ground-bait is an industry the practisers of which could probubly give moch information as to the nicety of choice exercised by flies in selecting material for feeding and egg-laying. According to Packard the house-fly makes selection of horse-dung by preference for ovipositirg, and as each female lays about 120 eggs and the cycle of changes from egg to fly is completed in less than

I The Lancet, March 16th, p. 786, and 30tb, 1901, p. 932 2 ThE I,ANCET, March 16th, 1901, p. 769. 
three weeks it seems probable that a female fly might have some $25,000,000$ descendants in the course of a hot summer. Other varieties of thies multiply, I believe, still more rapidly.

As flies multiply upon, and in, organic refuse of every kind it is obvious that the sooner such refuse is placed where it cannot serve for the feeding and hatching of flies the more likely is the plague of flies to be lessened. The most commonly available method for the bestowal of organic refuse is burial. The egg-laying of flies in dead carcasses commences at the very instant of death, or even before death in the case of enfeebled animals. This fact has been insisted upon by Megnin in "La - Faune des Cadavres" and appears to be true of human beings dying from fever. It is obvious, therefore, that there must be no delay in the burial of organic refuse and that the burial of animals and excreta is quite as important as the burial of human beings. After a great battle it may not be possible to follow this advice, bat nevertheless there can be no harm in insisting that the instant burial of all organic refuse must be the aim of those who are called upon to guard the public health, whether military or civil.

It is impossible to lay down any line of action which shall be the best under all circumstances, and those who, like myself, have not been through the South African campaign are incompetent to deal with the special circumstances of that campaign. Nevertheless, I am of opinion that much that I have witnessed on Salisbury Plain in connexion with campscavenging is bad and is not calculated to teach the soldier the right principles of dealing with organic refuse which is always his most dangerous enemy. The science of scavenging requires to be taught. If the duty of scavenging be left to the ignorant and be controlled by persons who think that necessary details are beneath their notice then annoyance and disease are the only results possible.

If the scavengings of a camp are to be satisfactorily dealt with the question of their nltimate disposal must be ever present in the mind of the scavenger. The materials collected have to be burnt, to be buried, or to be otherwise dealt with. The mere dumping of refuse in mixed heaps ought certainly to be abandoned and the contents of the latrines ought to undergo immediate superficial burial at the nearest available spot in order to avoid cartage and spilling. In many cases it should be possible to bury the excreta in the immediate vicinity of the spot where they are dropped. We hear of excreta being buried in trenches 10 feet deep, but such a course must mean that they are left exposed to give off odours and to breed flies for many hours before they are under yround and covered up. I bave consulted a gravedigger on this question and asked bim, "If you were ordered to dig a grave 10 feet deep what breadth and length wonld be necessary and what time would you require?" His reply was that (in chalk) the grave would have to be six and a balf feet long and three and a half feet wide, and that he would require a day and a half to complete the work. It is certain that 36 or 48 hours' delay in the disposal of fæces is most undesirable. I have always advocated the burial of fæces in shallow furrows rather than in deep trenches, and, in this country at least. where alone I have had experience, I am convinced that this is the only reasonable course to pursue. If properly done all offence to eyes or nose is thus ended and the fæces cease to attract either flies or rats. The fæces can be covered continuously as soon as they are dropped and there is no need of having malodorous open trenches partially filled which are waiting to be completely filled before being covered up.

This burial of fæces must be done methodically and carefally and with every attention to detail. The proceedings must be precisely those of a gardener who is intent upon raising crops. The fact that in war the crops may never be harvested is quite beside the mark and affords no excuse for slovenly procedures which are a danger to health Nitrification in the soil is the aim equally of the sanitarian and the agriculturist. If a plot of ground 50 yards long and 50 yards wide-slightly more than half an acre-be allotted for the disposal of fæces this should be marked off into, say, 16 strips, each about eight feet wide and 50 yards long, with a narrow path of about 18 inches between each strip to allow for watering and cultivation. The line of the furrows must be accurately marked by a cord and reel in the ordinary way, and the digger must move continuously backwards in order to avoid trampling on the freshly dug ground. The making of the furrows should commence at the point furthest from the latrines and it should gradually come nearer to them. The earth removed from the first furrow should be wheeled down near the latrines where it will be nltimately wanted to cover the last furrow which is dug. The capacity of the furrow or little trench will depend upon the size of the spade. I find that, working in ordinary garden soil with a spade having a blade nine inches long and seven inches wide (the furrow being consequently nine inches deep and seven inches wide), eight stable-bucketfuls of soil each holding two and a half gallons, or about 22 pounds weight of eartb, were removed. This amounts to two and a half bushels of soil, weighing 176 pounds, as the measure of the capacity of a trenchlet eight feet long. This trench must be filled with excreta and great care must be taken that nothing except fæces and paper and the accompanying urine is placed in it. If broken crockery or old tins are accidentally mixed with the excreta they must be removed. The trench being filled with fæces, mark out a djgging line at a distance equal to the width of the spade (seven inches) behind the edge of the first trench and then cover the faces in the first trench by the earth removed in making the second. Owing to the draining away of urine and moisture and their great compressibility it will be found that the excreta undergo a considerable diminution of bulk when tipped into the trench. When the earth of the second trench has been removed and shovelled on to the top of the first trench it will be found that there is a raising of the general level of the ground and the second trench will be found to have a cross section which is rather triangular than rectangular owing to the oblique direction of its front wall which is composed of a sloping bank of friable earth. The surface of the ground must be left crumbly, smooth, and perfectly neat, like a wellprepared garden bed. No particle of fæces or paper must be left uncovered. There will be no offence to eye or nose, no putrefaction is possible and the fæces are beyond the reach of dipterous insects, and if there has been no delay in the collection and burial of the fæces they cannot have been used for oviposition to any great extent, so that the soil will not become infested with " grubs."

How many men will provide the quantity of fæces which can be placed in a trench eight feet long from which 176 pounds weight of earth have been removed? The answer to this question is governed by bulk rather than by weight. If fæces and earth were equal in bulk for equal wejghts and if we allow a quarter of a pound of fæces tor each man-for the urine soaks away and guâ bulk may be neglected-then the answer would be $176 \times 4=704$. If the fæces are weight for weight four times as bulky as the earth, the answer is 176 . In any case it seems safe to say that a trench eight feet long, nine inches deep, and seven inches wide will suffice to take the frees of 100 men. This estimate entirely accords with my experience gained in my garden at Andover where the fæcal accumulations of 20 cottages have been disposed of daily in the manner indicated for 18 years and where it takes at least five years to cover an acre of ground in this way. Those who have not had experience of this method of dealing with fæces are apt to have exaggerated views as to the amount of land required. If a trench eight feet long and seren inches wide is sufficient for the disposal of the daily quota of excreta from 100 men, then 10 such trenches occupying an area of eight feet by 70 inches-say six feet-is enough for 1000 men and one strip of ground 50 yards long and eight feet wide would serve for a regiment of 1000 men for 25 days, and the 16 strips would serve for 400 days-let us say half an acre per annum per 1000 men. The actual area necessary will depend to some extent upon the nature of the soil and the care and skill of the scavenger, but in no case can the area required be regarded as a bar to the process - certainly not on the veldt or on Salisbury Plain. It need not be insisted on that a scavenger must be incessantly at work. The excreta should be taken up as soon as dropped and be placed in a covered pail, and the pail when full should be emptied into the furrow and covered up. In this way effluvia are stopped and ovipositing by diptera is rendered impossible. Further, this method of disposing of fæces necessitates no increase of the impedimenta of an army ; no lime or chemicals are needed and no apparatus beyond a spade and a set of garden tools.

The ground beneath which the fæces are deposited should when the work is done have the appearance of a wellprepared garden bed and it will need a little attention until it is covered with herbage of some kind. The only question remaining to be decided is as to what that herbage should be. There can be no camp without water-supply, and in every camp one of the sanitary problems is the disposal of waste water. Some of this waste water should be used in 
time of drought for laying dust and encouraging fertility in that small area of ground beneath the well-tilled surface of which the fæces are safely bestowed. Then, the higher the temperature the quicker will the ground bring forth green leaves to freshen the air. Whether the crop be grass, cabbage, cereals, onions, mustard and cress, lettuces, spinach, or what not must depend upon circumstances. I think the seeds sown in such ground should always be those of onlinary regetables which may prove a real blessing if the camp be long occupied. With a little care in a hot climate one may have a green covering of grass or mustard and cress in a week which at least will give off oxygen to the air even if it do not serve as an anti-scorbutic diet for man and beast-a diet which may just supply that something which is lacking in tinned and salted provisions.

In a temporary camp these methods of excrement disposal are the best on the grounds of immediate hygiene. In places like Salisbury Plain which are to be used as camping grounds year after year, latrine gardens are essential and, if properly managed, should furnish a good many acceptable extras for the canteens. Last year at Perham, on Salisbury Plain, there was a field of many acres occupied by the scavenging contractor and placed a few hundred yards from the camping ground. On this were piled heaps of camp refuse, old tins, meat bones, broken victuals, packing materials, and fæces which had been "dumped" with a view to burning when dry -enough. In their recent state these heaps (in which flies were swarming) could be smelt for a quarter of a mile down wind and when they began to burn the offensive smoke drifted still further and not seldom over the camps themselves. This haphazard method of "dumping "refuse in pestiferous heaps is not economical, not even from the point of view of the area of ground required, and would be rendered unnecessary by a little care in collection and the judicious ase of the spade by men who knew how to turn these despised materials to profitable account. Horse-dung in the same way should be neatly stacked in heaps like hotbeds, protected at the sides and covered with earth. In this way the flies would be prevented from feeding and egg-laying on the dung, large quantities of saladings might be produced, and when the camp was moved this well-rotted material should be applied to the camping ground with a view to the renovation of the turf. On Salisbury Plain the growth of summer is trodden under foot and there is no systematic renovation in the winter. On torf downs the actnal camping ground should be changed every year and the ground "top dressed" as soon as the camp breaks up in the autumn. Without careful management and good husbandry these downs will soon be trampled and scuffled into a dusty wilderness. In the same way all the kitchen refuse should (after utilisation to a maximam extent in the stock-pot, \&3.) be neatly stasked, protected at the sides, and covered with earth. All organic refuse should be completely protected by soil from the attacks of diptera and its fertilising properties should be utilised forthwith.

It is sometimes said that we ought to be ready to forgive the house-flies for the annoyance which they cause to us because of their great services as scavengers; but I am rather inclined to take the view that the presence of flies is a reproach to us for not putting organic refuse to its proper use. and that the fly is a robber which has been bred in material which we have deliberately allowed to lie above ground instead of covering it with soil. The scrupulous sweeping up of crumbs and food particles immediately after meals and the instant removal of the remains of food to $\mathrm{fl}_{\mathrm{l}}$-proof larders need not be insisted upon. I believe that a great advance in domestic hygiene will have been made when the custom is more general of removing dung every day from our stables, piggeries, cattle-sheds, and poultry-runs, and stacking it carefully so as to vrevent the access of diptera, or burying it immediately beneath the surface of well-tilled soil with a view to the production of crops. We pity the horse "turned nut" in a paddock when we see it tormented with "flies." Hew of us pause to think that if the horse-dung had been collected daily and put to more profitable use instead of being allowed to lie about and generate a plague of flies the animal might have been happier and the dung might have been more valuable for fertilising purposes. When flies breed in dung-heaps the larvæ eat the dung and leave the straw. If each fly needs one grain only of sustenance then the 25,000,000 which I have stated as the possible season's progeny of a female house fly will be capable of robbing a farmer of $25,000,000$ grains of fertilising material, which at 7000 graing to the pound works out at 3571 pounds, or considerably more than one and a half tons. It is bad economy to have your scavenging done by flies and sad to see your potential wealth make to itself wings and fly away. In my garden at Andover where human excreta have undergone daily superficial burial for about 18 years there is no excess of flies and I have come to the conclusion that an essential part of garden management is the daily collection of all garden offal, such as dead leaves, fallen and rotten fruit, \&c., and either superficially burying or stacking it so that it shall not serve as a breeding-ground for insects which often prey upon the plums and peaches in the autumn.

In the management of refuse I am no advocate for the use of chemical disinfectants. These are expensive, generally evil-smelling, of ten poisonous, and lead to an increase of material to be transported. The soil is quite capable, with proper management, of turning all organic refuse into "soil"-a fact which the experiments of Sir Eeymour Haden and myself have abundantly proved. Our experiments have also shown that from the point of view of the innocuons transformation of organic refuse into "soil" deep burial is a mistake. This is true alike of dead animals and of excreta. We are happily hearing less of the pollntion of the earth and of the growth of microbes and torins in the soil and even from the laboratories of bacteriologists we are learning that the soil is our best friend. The use of quick-lime in the treatment of excreta is, I believe, quite unnecessary. My experiments in burying small animals tend to show that the quick-lime preserves the body and mischievously prevents the beneficent action of the soil. In the management of refuse there must be no slovenly "dumping." What is wanted is proper sorting at the time of collection, great attention to detail, absolute neatness, and an appreciation of the ends to be attained.

In recommending the immediate collection of all organic refuse and its instant covering with earth I am making no new recommendation. Moses had had experience of a "plague of flies" in Africa and was no novice in the matter of camp-management. He found it necessary to be most explicit in his directions for the treatment of excreta. These directions are given in Deuteronomy xxiii., 12-14, and $I$ find that in the revised version of the English Bible there is an interesting change in the passage. The old version runs thus :

Thou shalt have a place also without the camp, whither thou shalt go forth abroad :

And thou shalt have a paddle upon the weapon; and it shall be, when thou wilt ease thyself [sittest down] abroad, thou shalt dig therewith, and cover that which cumeth from thee:

For the Lord thy God walketh in the midst of thy camp, to deliver thee, and to give up thine enemies before thee; therefore shall thy camp be holy: that he see no unclean thing in thee [nakedness of anything], and turn away from thee.

The new version says (verse 13): "Thou shalt have a paddle among thy weapous," and as a variant for paddle gives "shovel" in the margin. The passage, therefore, means that a shovel for burying excreta immediately is a necessary implement in every camp.

Portland-place, W.

\section{A CASE OF}

\section{SYMMETRICAL RETINAL DETACHMENT}

\section{OCCURRING DURING LABOUR AND} ASSOCIATED WITH ALBUMINURIA RESULTING IN COMPLETE RECOVERY.

BY RGGINALD G. HANN, M.R.O.S. ENG., L.R.O.P. LOND., AND

\section{R. LAWFORD KNAGGS, M.C. CaNtab., F.R.C.S. ENG.}

THE onset of sudden blindness during labour is a symptom which would naturally excite attention, but perhaps from the fact that a large majority of these cases recover vision and from the attendant circumstances the ocular conditions are not often investigated at the time. This no doubt accounts for the paucity of recorded cases. One cause of blindness during labour is retinal detachment in association with general cedema or eclampsia. The connexion of these 